\title{
Conveniently healthy: The impact of health endorsements on brand trust, brand loyalty and brand equity in Fast Moving Consumer Goods convenience versus shopping goods
}

\begin{tabular}{|c|c|}
\hline \multicolumn{2}{|c|}{$\begin{array}{l}\text { Authors: } \\
\text { Elsamari Botha }{ }^{1} \\
\text { Georgina Creaven } \\
\text { Jenna Mandy }{ }^{2}\end{array}$} \\
\hline $\begin{array}{l}\text { Affiliations: } \\
{ }^{1} \text { University of } \\
\text { Business Scho } \\
\text { University, Be } \\
\text { Cape Town, S }\end{array}$ & $\begin{array}{l}\text { Stellenbosch } \\
\text { ol, Stellenbosch } \\
\text { Iville, } \\
\text { uth Africa }\end{array}$ \\
\hline \multicolumn{2}{|c|}{$\begin{array}{l}{ }^{2} \text { Department of Marketing, } \\
\text { School of Management } \\
\text { Studies, University of } \\
\text { Cape Town, Cape Town, } \\
\text { South Africa }\end{array}$} \\
\hline \multicolumn{2}{|c|}{$\begin{array}{l}\text { Corresponding author: } \\
\text { Elsamari Botha, } \\
\text { elsamari.botha@usb.ac.za }\end{array}$} \\
\hline \multicolumn{2}{|c|}{$\begin{array}{l}\text { Dates: } \\
\text { Received: } 25 \text { Mar. } 2019 \\
\text { Accepted: } 04 \text { Feb. } 2020 \\
\text { Published: } 06 \text { Apr. } 2020\end{array}$} \\
\hline \multicolumn{2}{|c|}{$\begin{array}{l}\text { How to cite this article: } \\
\text { Botha, E., Creaven, G., \& } \\
\text { Mandy, J. (2020). } \\
\text { Conveniently healthy: The } \\
\text { impact of health } \\
\text { endorsements on brand } \\
\text { trust, brand loyalty and brand } \\
\text { equity in Fast Moving } \\
\text { Consumer Goods } \\
\text { convenience versus shopping } \\
\text { goods. South African Journal } \\
\text { of Business Management, } \\
51(1) \text {, a1535. https://doi. } \\
\text { org/10.4102/sajbm.v51i1.1535 }\end{array}$} \\
\hline \multicolumn{2}{|c|}{$\begin{array}{l}\text { Copyright: } \\
\text { (C) 2020. The Authors. } \\
\text { Licensee: AOSIS. This work } \\
\text { is licensed under the } \\
\text { Creative Commons } \\
\text { Attribution License. }\end{array}$} \\
\hline \multirow{2}{*}{$\begin{array}{l}\text { Read online: } \\
\text { 口ifr: }\end{array}$} & \\
\hline & $\begin{array}{l}\text { Scan this QR } \\
\text { code with your } \\
\text { smart phone or } \\
\text { mobile device } \\
\text { to read online. }\end{array}$ \\
\hline
\end{tabular}

Purpose: While millions of dollars is spent yearly on health endorsements, and its associated research, findings in studies where product category wasn't considered might be inaccurate.

Design/methodology/approach: An experimental research design was used to investigate the effect of health endorsements on FMCG brand loyalty, brand trust and brand equity of both convenience and shopping goods for 160 shoppers.

Findings/results: The study found that when looking at the impact of health endorsements overall, only brand trust was impacted. However, when distinguishing between product categories, health endorsements did not impact the brand trust, brand equity or brand loyalty of shopping goods, while having a great influence on those of convenience goods.

Practical implications: While most health endorsements are for shopping goods, these findings present an opportunity for marketers, to make better use of health endorsements in their packaging design. It presents an opportunity for health endorsers to target an untapped market, and it presents a challenge to producers to design convenience products worthy of health endorsements.

Originality/value: Studies considering the return on investment of health endorsements must consider the product category, in order to decrease the likelihood of encountering misleading results as the influence of health endorsements greatly differ between products.

Keywords: health endorsements; product category; brand trust; brand loyalty; brand equity; Fast Moving Consumer Goods.

\section{Introduction}

Branding in the Fast Moving Consumer Goods (FMCG) industry has been a major focus of research over the past few decades, as better understanding of brands enables firms to differentiate their products in a highly competitive market (Celen, Erdogan, \& Taymaz, 2005; Gonzalez, 2009; Nijssen, 1999). In a market where consumers are spoilt for choice, companies use what they can to differentiate their brands. One such strategy is to get health endorsements for their products. Health endorsements are a form of differentiation for firms and can be used as a marketing tool (Graham, Harker, Harker, \& Tuck, 1994; Young \& Swinburn, 2002). In particular, health endorsers argue that their 'independent' stamp of approval provides additional value to health conscious consumers.

Research suggests that the positive associations generated by these health endorsements may positively affect the brand of the endorsed product (Graham et al., 1994; Yoo, Donthu, \& Lee, 2000; Delgado-Ballester \& Munuera-Aleman, 2001; Garbarino \& Johnson, 1999). Most studies, however, investigate health claims made by the brands themselves, as opposed to independent agencies. Williams (2005), for example, showed how health claims cause a 'halo effect' and inhibit consumers from seeking further nutrition information. Levin and Levin (2010), on the contrary, looked at packaging in general and its influence on healthy food choice. And while an increasing number of studies investigate the impact of celebrity endorsements (e.g. Malik \& Guptha, 2014), few investigate the impact of third-party health endorsements on the brand. As an increasing number of products become endorsed, its effect, and whether this effect holds across different product categories, is unclear: do health endorsements influence shopping versus convenience goods differently? In Holton's (1958) classic definition of types of goods, shopping goods are defined as 
those that consumers spend time evaluating based on price, quality and competing products. Convenience goods, on the contrary, are those products purchased frequently, immediately and with little effort (Holton, 1958). While previous research has investigated the influence of product involvement on health endorsements (Montandon, Ogonowski, \& Botha, 2017), the influence of health endorsements on brand dimensions between different product categories remains unclear. Therefore, in addition to understanding the effect of health endorsements on brand perceptions, this study investigates whether the same influence is experienced across product types.

Three key components of a brand that might be influenced by health endorsements are brand trust, brand loyalty and brand equity (Delgado-Ballestar \& Munuera-Aleman, 2001, 2005). Brand trust can be described as the degree to which consumers believe that their expectations will be met by the brand (Delgado-Ballester \& Munuera-Aleman, 2001). Garbarino and Johnson (1999) believed that brand trust is determined by the consumption experience, and that it is essential for creating future repurchase decisions. Brand loyalty can be described as the consumer's decision to continually repurchase a brand (Arens, Weigold, \& Arens, 2011). Brand loyalty is essential in building longterm relationships with consumers and ensuring commitment to the brand over competing brands (Chaudhuri \& Holbrook, 2001; Cyr, Hassanein, Head, \& Ivanov, 2007). Finally, brand equity can be described as the value added to a product through its brand name (Yoo et al., 2000). Brand equity can be instrumental in developing competitive advantage, increasing cash flows and making the firm less susceptible to competitor actions (Yoo et al., 2000). These three brand aspects - brand trust, brand loyalty and brand equity - are significant components of a strong brand (Ford et al., 2015; Yoo et al., 2000). Consequently, for understanding the impact of health endorsements on product brands, these three dimensions of a brand need to be considered. The aim of this study was therefore twofold: firstly, to determine the impact of health endorsements on the brand trust, brand loyalty and brand equity of FMCG products; secondly, to determine if this impact is the same across different product types, specifically convenience versus shopping goods.

This article starts with a review of relevant literature regarding health endorsements, branding and the FMCG industry. Then, the methodology and fieldwork for this study are outlined. The results are then analysed and followed by a discussion and conclusions that were drawn from the findings.

\section{Health endorsements}

Health endorsements on food products are used to indicate healthy or healthier choices using an on-pack symbol (Rayner, Boaz, \& Higginson, 2001). Only products that comply with the endorsement's criteria are eligible to obtain the endorsement (Graham et al., 1994; Rayner et al., 2001). One of the earliest instances of the use of a health endorsement was in 1984 by Kellogg's who arranged with the National Cancer Institute to endorse Kellogg's All Bran cereal. Over the following 6 months, All-Bran's market share rose by 47\%, indicating the huge impact a health claim can have on consumer perceptions. Endorsements relating to nutritional food quality began to emerge in America in 1995 and since then the use of these health symbols has grown substantially (Nestle \& Ludwig, 2010).

An analysis conducted by the World Health Organization in 2000 indicated an increasing global trend towards obesity and unhealthy living, which is evident in both developed and developing countries (Mhurchu \& Gorton, 2007; World Health Organization, 2000). As a result, health awareness has risen drastically, and the use of health endorsements on food products has become increasingly relevant (Mhurchu \& Gorton, 2007; Nestle \& Ludwig, 2010; Steenhuis et al., 2010). Many health-related programmes have been developed, such as the 'Pick the Tick' food endorsement programme in New Zealand and Australia, retailer endorsements in the United Kingdom, and the Canadian 'Healthy Restaurants' programme (Graham et al., 1994). These programmes aim to promote healthy living by making it easier for consumers to make informed product choices and build healthier diets (Graham et al., 1994; Nestle \& Ludwig, 2010).

Consumer attitudes and perceptions of a product may be positively altered by health endorsements. This could have a beneficial impact on branding from which firms stand to gain financially (Kozup, Creyer, \& Burton, 2003; Nestle \& Ludwig, 2010). The reported use of health endorsements by consumers is high. Young and Swinburn's (2002) study found that $59 \%$ of consumers reported purchasing products with the New Zealand 'Pick the Tick' food endorsement logo where they could. This is reinforced by Graham et al.'s (1994) research on the Australian 'Pick the Tick' logo, which found that the logo was effective in assisting shoppers to assess the healthy product options quickly and easily (Graham et al., 1994).

The positive associations generated by health endorsements have the potential to benefit brands by reinforcing differentiation (Graham et al., 1994), and firms can experience large financial gain as demonstrated by the All-Bran case study (Mazis \& Raymond, 1997).

\section{Branding}

Brands communicate value, an image or lifestyle, enabling consumers to interact and establish a relationship with the brand (Rooney, 1995). Cleary (1981) also argued that a predominant purpose of branding is to enhance the product's image. This influences the perceived worth of the product and leads to increased brand value for the customer (Cleary, 1981). Brands provide a focal point for consumer's expectations, thus decreasing search time with regard to the purchase decision (Ford et al., 2015). 
Brand trust, brand loyalty and brand equity are essential branding aspects in determining a brand's success. These three brand aspects will be explored further in the following section.

\section{Brand trust}

The concept of brand trust is derived from the fields of social psychology, sociology, management and marketing and is defined as a feeling of security, which a consumer has with a particular brand and the degree to which the consumer feels that the brand will meet his or her expectations (Delgado-Ballester \& Munuera-Aleman, 2001).

Garbarino and Johnson's (1999) definition of brand trust is consistent with that of Delgado-Ballester and MunueraAleman (2001). Garbarino and Johnson (1999) argued that the consumption experience is the ultimate determinant of brand trust, as it creates a direct relational interaction between the consumer and the brand. Brand trust also implies that consumers expect a certain level of performance from the brand. This is essential for the consumers in perceiving the brand to be reliable and for creating future repurchase intentions (Delgado-Ballester \& Munuera-Aleman, 2001). Thus, it is necessary for firms to establish brand trust to increase the likelihood of repeat brand purchases.

Lau and Lee (1999) provided further insight into the concept of brand trust, defining it as the willingness to rely on a brand in the face of risk, with the expectation that the brand will lead to positive outcomes. This willingness stems from a familiarity with the brand based on past experience (Lau \& Lee, 1999). If the usage experience of the brand at least meets the consumer's expectations, the good brand reputation reaffirms the consumer's trust in the brand (Lau \& Lee, 1999).

Also, if consumers perceive a brand to offer a unique value offering over competing brands, consumers demonstrate a higher degree of brand trust (Chaudhuri \& Holbrook, 2001). This suggests that there is incentive for brands to establish a unique value offering to heighten consumers' trust in the brand and increase the likelihood of repeat purchases.

Health endorsements provide a unique value offering for consumers in the form of a promise of a healthy purchase (Graham et al., 1994). If consumers view the health endorsement as being able to deliver its promised value, they are more likely to associate the product with a credible and reliable brand (Graham et al., 1994). Brand reliability is necessary to establish brand trust and as such health endorsements have the potential to increase consumers' trust in the endorsed brands. However, the effects of health endorsements on brand trust are relatively unknown. This study aims to determine whether brand trust is elevated by the presence of a health endorsement and thus the following hypotheses were tested:
H1: Health endorsements influence the brand trust of products for female shoppers.

H1a: Health endorsements influence the brand trust of convenience products for female shoppers.

H1b: Health endorsements influence the brand trust of shopping products for female shoppers.

H2: Health endorsements have a greater influence on the brand trust of convenience goods than the brand trust of shopping goods.

The study by Lau and Lee (1999) found that when a consumer has established trust in a brand, and demonstrates a willingness to depend on that brand, they are also likely to form a favourable buying intention towards the brand. Garbarino and Johnson (1999) stated that trust is the predominant driver of loyalty, as it creates interactive relationships that are highly valued by both the consumer and the brand. Thus, brand trust is positively related to a consumer's loyalty to a brand (Lau \& Lee, 1999). Chaudhuri and Holbrook (2001) also emphasised that brand loyalty is built on the concept of trust and cannot be established without it. Thus, brand trust is a necessary element in creating brand loyalty.

\section{Brand loyalty}

Brand loyalty is the consumer's expression of his or her overall satisfaction with the brand's performance (Bloemer \& Kasper, 1995). Arens et al. (2011, p. 645) reaffirmed this by defining brand loyalty as 'the consumer's decision, expressed through intention or behaviour, to repurchase a brand continually'. Therefore, brand loyalty is seen as a key element in predicting consumer behaviour (Delgado-Ballester \& Munuera-Aleman, 2001).

Brand loyalty is a measure of the attachment or commitment that a customer has to a brand and benefits the firm by leading to repeat purchases and positive word of mouth (Aaker, 1991; Lau \& Lee, 1999). Jacoby (1971) was among the first to explore the idea of brand loyalty as a multidimensional construct, which involves attitudinal and behavioural components: the attitudinal component referring to consumers' attitude and feeling towards the brand and the behavioural component referring to the actual behavioural interactions with the brand (Arens et al., 2011).

The multidimensional approach to brand loyalty is also emphasised by Delgado-Ballester and Munuera-Aleman (2001) who argued that brand loyalty is not only concerned with the intention of repeat purchase but is just as focussed on consumers' internal attitude and emotional attachment to the brand. Therefore, the behavioural component alone does not provide an adequate basis for establishing brand loyalty in the brand-consumer relationship (Delgado-Ballester \& MunueraAleman, 2001). The presence of both dimensions of brand loyalty is necessary in maintaining a valued and long-term relationship between the consumer and the brand (Chaudhuri \& Holbrook, 2001). Thus, it is essential for firms to establish brand loyalty to maintain and grow their customer base and obtain a competitive advantage in the marketplace. 
To measure brand loyalty, a study by Bloemer and Kasper (1995) took into account the degree of consumers' commitment to the brand. They defined this commitment on a continuum, the one end being true brand loyalty and the other end of the continuum being spurious brand loyalty (Bloemer \& Kasper, 1995). True brand loyalty is based fully on brand commitment, whereas spurious brand loyalty is based on a convenience purchase and contains no level of commitment to the particular brand. However, this approach to measuring brand loyalty has been criticised for focussing on consequences of loyalty in the form of consumers' purchasing behaviour and not actual loyalty (Odin, Odin, \& Valette-Florence, 2001). The study conducted by Odin et al. (2001) aimed to establish a reliable measure of brand loyalty, which incorporates both the behavioural and attitudinal dimension. They measured brand loyalty according to consumers' willingness to switch brands, willingness to go to another shop to obtain a particular brand and willingness to pay a premium for their preferred brand.

The use of health endorsements for products increases the likelihood that consumers will commit to buying the product for health-related reasons (Graham et al., 1994). The presence of the health endorsement is also likely to generate a positive emotional response from consumers, as the brand is perceived to be concerned with consumers' well-being (Steenhuis et al., 2010). Brand commitment and a positive attitudinal association are necessary components of brand loyalty (Odin et al., 2001). To establish whether brands endorsed by a health programme portray a higher degree of brand loyalty than brands which are not, the following hypotheses were tested:

H3: Health endorsements influence the brand loyalty of products for female shoppers.

H3a: Health endorsements influence the brand loyalty of convenience products for female shoppers.

H3b: Health endorsements influence the brand loyalty of shopping products for female shoppers.

H4: Health endorsements have a greater influence on the brand loyalty of convenience goods than the brand loyalty of shopping goods.

Cyr et al. (2007) defined brand loyalty as a consumer's commitment to a particular brand when choosing between two or more products. It can be concluded that brand loyalty provides firms with a competitive advantage in the marketplace, as consumers who are brand loyal are more likely to make repeat purchases continually and disregard competing brands. This loyalty to a brand name forms the basis of brand equity (Aaker, 1991). Delgado-Ballester and Munuera-Aleman (2001) further argued that brand loyalty is the fundamental component in creating brand equity, as it creates measurable marketing advantages. Thus, a consumer's loyalty to a particular brand has a favourable effect on brand equity.

\section{Brand equity}

Brand equity is the value added to a product by its brand name (Lassar, Mittal \& Sharma, 1995; Yoo et al., 2000). Essentially, this is the difference in consumer choice of a branded product and an unbranded product when both products have the same level of product features and marketing stimuli (Keller, 1993). It is important to note that brand equity is a consumer perception; therefore, it is not an objective construct, and it is also relative to market competition (Lassar et al., 1995). Brand equity is a substantial asset to a firm, as it increases cash flow and is critical in developing a competitive advantage (Lassar et al., 1995; Yoo et al., 2000). It can influence the buying behaviour of consumers by increasing the probability of brand choice, willingness to pay a price premium, marketing communications' effectiveness and licensing opportunities (Ford et al., 2015). In addition, it decreases the vulnerability of a brand to competitors' actions and decreases the effect of price changes on the firm (Ford et al., 2015). Therefore, brand equity is an important brand aspect for firms.

A study conducted by Aaker (1991) described brand equity as a set of assets, such as name awareness, brand loyalty, perceived quality and brand associations, that are linked to the name of a brand. Brand equity can also be very beneficial to consumers, as it enables them to interpret, process and store large amounts of product information (Aaker, 1991). It can also enhance the confidence they have in their purchasing decisions, as the perceived quality of the product is much higher (Ford et al., 2015). These positive associations can serve to elevate customer satisfaction (Yoo et al., 2000).

Aligned with Aaker (1991), Yoo et al. (2000) viewed brand equity as a multidimensional construct, which consists of four dimensions: perceived quality, brand loyalty, brand associations and brand awareness. A brand equity scale developed by Lassar et al. (1995) was based on five underlying constructs: performance, social image, value, trustworthiness and commitment. The study emphasised that all these underlying constructs should be regularly evaluated by companies to create strong brand equity (Lassar et al., 1995).

In spite of the various measurement methods of brand equity, there is a wide acceptance of the importance of the brand equity construct in providing benefits to firms. Yoo and Donthu (2001) believed that almost every marketing function is executed with the intention of building, managing and exploiting brand equity. Brands with high brand equity have a significant advantage over competitors with low brand equity and have more freedom and influence within their markets (Lassar et al., 1995). Brand equity is a fundamental characteristic in building a strong brand, and it is thus an important brand aspect to consider in this study.

Health endorsements have the potential to increase aspects such as brand association, brand loyalty and perceived quality (Graham et al., 1994; Kozup et al., 2003; Steenhuis et al., 2010). These are all dimensions of brand equity. However, little formal research has been conducted regarding the link between brand equity and health endorsements. Therefore, this study aims to provide further insight into this link and, as a result, the following hypotheses shall be tested:

H5: Health endorsements influence the brand equity of products for female shoppers. 
H5a: Health endorsements influence the brand equity of convenience products for female shoppers.

H5b: Health endorsements influence the brand equity of shopping products for female shoppers.

H6: Health endorsements have a greater influence on the brand equity of convenience goods than the brand equity of shopping goods.

From the literature discussed above, it is evident that brand trust, brand loyalty and brand equity play fundamental roles in building a long-lasting, successful brand. Therefore, these three brand aspects will be used as measures of the overall effect of health endorsements on the brand. Health endorsements are widely used on food products - a sector of the FMCG industry (Celen et al., 2005). Food endorsement programmes are the focus of this study, and therefore FMCGs are an important research component.

\section{Fast Moving Consumer Goods}

Fast Moving Consumer Goods account for a large portion of consumers' budgets around the world (Celen et al., 2005). Competition in this industry is high mainly because of low operational costs (Gonzalez, 2009; Nijssen, 1999). Fast Moving Consumer Goods products include goods that are consumed regularly, and consumers often have low involvement during these purchase decisions (Gonzalez, 2009; Nijssen, 1999). Fast Moving Consumer Goods are very prominent in the retail sector, and food products form a large part of the FMCG market (Celen et al., 2005; Gonzalez, 2009). Branding is highly important in this industry, as it allows firms to differentiate their products and create line extensions (Nijssen, 1999). A significant aspect of this study is to determine whether the effect of health endorsements on brand aspects differs across product categories. Thus, a classification system originally developed by the American Marketing Association's Committee on Definitions and later altered by Holton (1958) and Bucklin (1963) will be used. This system shall be discussed below.

Both Holton (1958) and Bucklin (1963) used the category of shopping goods in their papers. Holton (1958) described shopping goods as goods that are evaluated by consumers during the selection and purchasing process. Comparisons are made with other goods on the basis of various aspects, such as suitability, quality, price and style (Holton, 1958). The gain from making comparisons is thought to outweigh the (high) search costs encountered (Holton, 1958). Often, with this category of goods, consumers enjoy shopping for them or value the gain from a better buy (Holton, 1958). Bucklin (1963) wished to add to Holton's definition by including that consumers have a lack of complete consumer knowledge about the product they wish to buy (Bucklin, 1963). He also added that changes in aspects of the product, such as style, technology or pricing, are frequent, causing consumer knowledge to become obsolete. This often occurs when there are time lapses in between purchases or when consumer needs are subject to change (Bucklin, 1963).
The second category identified by Holton (1958) is convenience goods, which include goods that are purchased frequently, immediately and with little effort during the buying process (Holton, 1958). Consumers spend little time in making price and quality comparisons with competing products and rather value the item for the saving on search costs in terms of time, money and effort (Holton, 1958). Bucklin (1963) further defined a convenience good as a good where all products in a category are ranked evenly in the mind of the consumer, wherein the most accessible option is purchased (Bucklin, 1963). Therefore, for this category, the search costs and the effort required are very low.

For the purposes of this study, shopping goods and convenience goods have been chosen to establish whether there is a difference in the effect of health endorsements on brand aspects across product categories. These categories were selected as they have the most variance in relation to search costs and purchase involvement and therefore a difference, if it exists, will be identified more easily. Kozup et al. (2003) found that health claims had the largest influence when no nutritional information panel was provided, which suggests that health claims are most effective when placed on the front of products. These consumers are not searching for additional information and therefore are more likely to purchase a convenience good than a shopping good. This suggests that health logos on the front label may have a larger effect for convenience goods than for shopping goods.

This study was conducted using a South African health endorsement programme. The programme is independently run, profit-generating and endorses products that meet a set strict, heart healthy criterion.

\section{Methodology}

This study conducted a causal research, as it aimed to obtain evidence of a cause and effect relationship between health endorsements and branding. An experimental design was used to test this causal relationship, and a field experiment was conducted. In this study, health endorsements were represented by the Heart Mark, which is a recognised South African nutritional logo (Heart Mark, 2012). The Heart Mark was the independent variable or treatment, and the three brand aspects - brand trust, brand loyalty and brand equity - were the dependent variables used to measure the overall effect of health endorsements on brands. The brand trust construct was measured using a scale from Delgado-Ballester and Munuera-Aleman (2001). The scale used to measure brand loyalty was obtained from Odin et al. (2001), and the brand equity construct was measured using a scale from Yoo and Donthu (2001).

Atwo group experimental design was used; the experimental group was exposed to the treatment (the health endorsement) and the control group was not exposed to the treatment. The experimental group was only measured after the 
exposure to the treatment to determine the effect of the health endorsement on the dependent variables. This type of experimental design was chosen, as it is the best design to use for this study to measure the difference in the brand aspects between a health-endorsed food product and a food product, which is not endorsed. In addition to this, a secondary objective aimed to establish if the treatment effect differed with regard to two types of goods: convenience goods and shopping goods. Thus, four groups were created to test this effect, and these groups are shown in Table 1.

Females were chosen as the target population for this study because of the prominent role they play in household shopping and their greater involvement with nutritional logos (Catalyst, 2011; Vyth et al., 2009). Non-probability convenience sampling procedure was used as part of the mall intercept approach.

\section{Fieldwork}

Two fieldworkers stood outside the entrances of two FMCG store branches, and respondents were selected based on the specified target population. The two areas were selected to increase the generalisability of the sample. In addition, data were collected at various times over a 2-week time frame to reduce bias. No incentives were offered to respondents. One product from each product category was selected: a local yoghurt brand as the shopping good and a local bread brand as the convenience good. These brands were selected as they are both of the most purchased brand in each category at the time to account for shopper familiarity. In addition, both brands were purchased by shoppers from various income groups, and were a part of a highly contested price sensitive product category (which meant that shoppers were more likely to switch brands in these categories and not remain brand loyal). The division of respondents is shown in Table 1. At each store, the 80 respondents were divided equally between the four groups (see Table 1).

Each group in Table 1 was given an information card. One card stated that the product had recently received a health endorsement, while the other stated that it had not received a health endorsement. This was done for both the shopping good and the convenience good. After reviewing the information cards, the respondents were asked to fill in a questionnaire about the brand on the information card that they received. In this way, two groups of consumers could be compared to assess whether, overall, the presence of the health endorsement had an effect on consumers' level of brand trust, brand loyalty and brand equity (groups 1 and 3 were compared to groups 2 and 4 in Table 1). In addition, Group 1 was compared to Group 3 to determine if the brand

TABLE 1: Depiction of the respondent group

\begin{tabular}{lll}
\hline Product type & Heart mark & No heart mark \\
\hline Shopping goods & Group 1: 40 shoppers & Group 2: 40 shoppers \\
Convenience goods & Group 3: 40 shoppers & Group 4: 40 shoppers \\
\hline
\end{tabular}

aspects differed between the two goods categories when both are were endorsed.

\section{Ethical consideration}

Ethical clearance was obtained from the University of Cape Town.

\section{Results}

Interesting findings were obtained from this study, and these are detailed in the following section. Firstly, the scale validity and reliability was determined, followed by a review of the descriptive statistics. Following this, the outcomes of the hypothesis tests were addressed, as they pertained to the research objectives.

\section{Scale reliability}

To assess the validity and reliability of the scales used in this study, a factor analysis using a varimax normalised rotation was conducted, and the Cronbach's alpha of the items was reviewed.

The construct of brand trust was measured using six items. The factor analysis used for this construct showed that all the items loaded onto one factor with an eigenvalue of 4.36. Around $72.68 \%$ of the variation was explained by this factor, which indicates that all the items are highly correlated together. The Cronbach's alpha for brand trust was 0.92 , which is greater than the accepted value of 0.70 . This alpha value would not increase if items were deleted. Thus, the factor analysis and the high Cronbach's alpha value indicate that the measurement of this construct is valid and reliable.

Brand loyalty was measured using 16 items that loaded onto three factors when the factor analysis was conducted. The eigenvalues for the three factors were 8.95, 1.96 and 1.08, and each factor explained $55.92 \%, 12.23 \%$ and $6.73 \%$ of the variation, respectively. This indicates that the scale consists of three dimensions that measure brand loyalty. The Cronbach's alpha value for brand loyalty was 0.94 , which is higher than 0.70 , and thus the construct's measurement is acceptable. Therefore, it is not necessary to delete any items from the scale. Both the factor analysis results and the Cronbach's alpha value indicate that the construct is reliably and validly measured.

The brand equity construct was measured using a 14-item scale. Although the study from which this scale was extracted stated that the construct is made up of four dimensions, the factor analysis conducted for this study showed that the items load onto only two factors, suggesting that the scale consists of two dominant dimensions that measure brand equity. The eigenvalues for each factor were 8.30 and 1.11, and each of the factors explained $59.30 \%$ and $7.92 \%$ of the total variation, respectively. The Cronbach's alpha for this construct was 0.94 , which is well above the accepted value of 0.70 for reliability. Therefore, it is not necessary to delete any 
items from the scale. The factor analysis results and the Cronbach's alpha value suggest that the scale used to measure brand equity is valid and reliable.

\section{Descriptive statistics}

The descriptive statistics analysed below aim to give an overview of the overall dataset as well as the two groups of respondents created: the endorsed group and the not endorsed group. The mean and standard deviations for the brand trust, brand loyalty and brand equity constructs are shown in Table 2.

Three is the neutral point on the 5-point Likert scale used in this study, and the mean for all of the constructs is above 3 . Therefore, on average, the data tended towards the 'agree' portion of the scale. The variation in the constructs is similar, which is demonstrated by the similar standard deviation values. Because this study used an experimental design, it is important that the two groups in the study, endorsed and not endorsed, are alike. The groups should be similar with respect to the descriptive statistics collected. These descriptive statistics are shown in Table 3.

An independent sample $t$-test was conducted to establish if the two groups were similar with respect to their scores on age, health consciousness and shopping frequency. The two groups significantly differed only with regard to shopping frequency $(p=0.01)$. However, the actual value of the difference was only 0.34 , so this finding shall not affect the results of this study.

\section{Results regarding the individual objectives}

Hypothesis tests were conducted to establish the outcomes of the objectives of this study. Objective 1 was to establish whether products with health endorsements have a higher level of brand trust, brand loyalty and brand equity than products that do not have health endorsements among the selected target market. Objective 2 aimed to establish if the effect of the health endorsement differs depending on the product type. Independent sample $t$-tests were conducted for all the hypotheses in this study, and the $p$-values were evaluated at the $5 \%$ level of significance. The findings are detailed in the following section.

TABLE 2: Descriptive statistics for brand trust, brand loyalty and brand equity.

\begin{tabular}{lcc}
\hline Key constructs & Mean & Standard deviation \\
\hline Brand trust & 3.67 & 0.89 \\
Brand loyalty & 3.14 & 1.01 \\
Brand equity & 3.69 & 0.92 \\
\hline
\end{tabular}

TABLE 3: Descriptive statistics for endorsed group and not endorsed group.

\begin{tabular}{lcccc}
\hline Variable & \multicolumn{2}{c}{ Endorsed } & \multicolumn{2}{c}{ Not endorsed } \\
\cline { 2 - 5 } & Mean & Standard deviation & Mean & Standard deviation \\
\hline Age & 42.53 & 9.20 & 41.10 & 8.95 \\
Shopping frequency & 4.28 & 0.97 & 4.62 & 0.74 \\
Health consciousness & 3.90 & 0.99 & 4.09 & 0.87 \\
\hline
\end{tabular}

Results pertaining to objective 1: Impact of health endorsements on the brand

Hypotheses H1, H1a, H1b, H3, H3a, H3b, H5, H5a and H5b were tested to establish the outcome of objective 1 for this study, which concerned the impact of health endorsements on various elements of the product brand. In addition, we investigated whether this impact differed between these product categories (Table 4 ).

When looking at both product categories at the same time (i.e. overall), health endorsements only impacted brand loyalty ( $p=0.048$ ), narrowly approaching the 5\% level of significance cut-off. When distinguishing between product categories, however, these findings suggest that this might be misleading: health endorsements significantly influenced the brand for convenience goods. While having no impact on the brand trust $(p=0.45)$, brand loyalty $(p=0.35$ ) or brand equity ( $p=0.50)$ of shopping goods, it had a great impact on all the elements related to convenience brands (brand trust $p=0.00$; brand loyalty $p=0.02$; brand equity $p=0.03$ ). In all these cases (i.e. H1, H1a, H2a and H3a), shoppers preferred the products with the health endorsement.

These findings show that health endorsements only influenced the brands of convenience products, and not those of shopping products. The next objective delves further into the difference between the types of products.

\section{Objective 2: Overall impact of product type}

The findings with regard to objective 1 indicated that health endorsements had a greater influence on convenience, as opposed to shopping goods, when looking at each type of product. The second objective approaches this question from the perspective of the brand and tests the overall difference between convenience and shopping goods with regard to brand trust, brand loyalty and brand equity to confirm these results. The hypotheses relating to this objective are $\mathrm{H} 2, \mathrm{H} 4$ and H6 (Table 5).

All three hypotheses were confirmed, as the null hypotheses to all three were rejected $(p<0.05)$. This meant

TABLE 4: Summary of statistics pertaining to objective 4.

\begin{tabular}{|c|c|c|c|c|}
\hline \multirow[t]{2}{*}{ Hypothesis } & \multirow[t]{2}{*}{$p$} & \multicolumn{2}{|c|}{ Mean } & \multirow[t]{2}{*}{ Result } \\
\hline & & $\begin{array}{c}\text { With } \\
\text { endorsement }\end{array}$ & $\begin{array}{c}\text { Without } \\
\text { endorsement }\end{array}$ & \\
\hline $\mathrm{H} 1$ - Brand trust & 0.048 & 3.79 & 3.55 & Significant \\
\hline $\begin{array}{l}\mathrm{H} 1 \mathrm{a}-\text { Brand trust } \\
\text { (convenience) }\end{array}$ & 0.00 & 4.14 & 3.15 & Significant \\
\hline $\begin{array}{l}\text { H1b - Brand trust } \\
\text { (shopping) }\end{array}$ & 0.45 & n.a. & n.a. & Not significant \\
\hline H3 - Brand loyalty & 0.24 & n.a. & n.a. & Not significant \\
\hline $\begin{array}{l}\text { H3a - Brand loyalty } \\
\text { (convenience) }\end{array}$ & 0.02 & 3.68 & 3.17 & Significant \\
\hline $\begin{array}{l}\text { H3b - Brand Loyalty } \\
\text { (shopping) }\end{array}$ & 0.35 & n.a. & n.a. & Not significant \\
\hline H5 - Brand equity & 0.64 & n.a. & n.a. & Not significant \\
\hline $\begin{array}{l}\text { H5a - Brand equity } \\
\text { (convenience) }\end{array}$ & 0.03 & 4.04 & 3.66 & Significant \\
\hline $\begin{array}{l}\text { H5b - Brand equity } \\
\text { (shopping) }\end{array}$ & 0.50 & n.a. & n.a. & Not significant \\
\hline
\end{tabular}

n.a., not applicable. 
TABLE 5: Results of hypotheses 2, 4 and 6.

\begin{tabular}{lcl}
\hline Hypothesis & $p$ & Result \\
\hline $\mathrm{H} 2-$ Brand trust & 0.00 & Reject H0 \\
$\mathrm{H} 4-$ Brand loyalty & 0.00 & Reject H0 \\
$\mathrm{H} 6-$ Brand equity & 0.00 & Reject H0 \\
\hline
\end{tabular}

that health endorsements had a greater influence on the brand trust, brand loyalty and brand equity for convenience goods than they did for shopping goods. In fact, the previous section shows that health endorsements did not have any influence on how the consumers assessed the shopping goods brands.

\section{Conclusion}

The aim of this study was to establish whether health endorsements of food products have a positive effect on brands. Brand trust, brand loyalty and brand equity were used to measure the effect. Furthermore, this study aimed to determine whether this effect differed across product types. Studies where no distinction is made between product categories might deliver misleading results, as this study showed that the overall impact of health endorsements on the brand was not always evident; however, when the product category was considered, that influence became significant.

Health endorsements influenced consumers' brand trust, brand loyalty and brand equity of convenience goods, but the same was not observed for shopping goods. Indeed, health endorsements had no effect on shopping goods. However, this product category is typically found where health endorsements can be found; for example, with oils, butter and tinned goods, this study shows that no effect was observed. This might be an indication of market saturation where consumers expect, or are no longer impressed with endorsed products.

However, there is an opportunity for convenience goods to be endorsed, as this had a great impact on the product's brand. This finding was supported by Kozup et al. (2003) who established that health claims were most effective when appearing on products that do not require a high degree of involvement in the purchase. We suspect that the additional information presented by the health endorsement assists consumers in making the 'quick decision' associated with most convenience goods.

\section{Managerial implications and recommendations}

Health endorsements may represent a differentiating factor that could lead to a stronger brand as well as financial rewards for the company (Mazis \& Raymond, 1997), but they also mean that the company needs to incur costs (and possibly increase the price of the product as a result). Managers who have products in the convenience goods category are more likely to experience differentiation through using a health endorsement and thus yield a return on investment.
Managers operating in the convenience goods industry who are looking to raise the strength of a current brand or build a new brand should consider health endorsements as a means of achieving this. An increase in brand trust is associated with an increased likelihood of consumers making future repurchases (Garbarino \& Johnson, 1999). An increase in brand loyalty is most importantly associated with creating a competitive advantage in the marketplace as consumers, who are brand loyal, are more likely to continually make repeat purchases and disregard competing brands (Cyr et al., 2007). Brand equity increases the likelihood that consumers will choose that particular brand as well as pay a price premium over competing brands (Yoo et al., 2000). Thus, from a managerial point of view, health endorsements of convenience goods could potentially be a lucrative value-adding tool for brands within this category. For shopping goods, however, it might be an unnecessary expense.

Studies considering the return on investment of health endorsements must consider the product category, to decrease the likelihood of encountering misleading results as the influence of health endorsements greatly differ between products. In addition, while most health-endorsed products fall under the shopping goods category, this study found that the influence of the endorsement on the brand was marginal and only brand trust increased significantly with the endorsement. However, health endorsements had an influence on the brand trust, brand equity and brand loyalty of convenience goods. This might be because so few convenience goods are endorsed (as the majority of convenience goods cannot be endorsed by their nature, e.g., chocolates), or because of the comparatively little time that consumers spend in the selection of the product. For the latter, the addition of the health endorsement might assist the shopper in the paradox of choice (Schwartz, 2016). Regardless of the mechanism, these findings present an opportunity for both marketers and producers to not only consider health endorsements for this product category but also to produce convenience products that are worthy of health endorsements.

\section{Acknowledgements}

The authors would like to thank the National Research Foundation Thuthuka Fund for the financial assistance.

\section{Competing interests}

The authors have declared that no competing interests exist.

\section{Authors' contributions}

All authors contributed equally to the writing of this article.

\section{Funding information}

This study was funded by the National Research Foundation Thuthuka Funding programme. 


\section{Data availability statement}

Data sharing is not applicable to this article as no new data were created or analysed in this study.

\section{Disclaimer}

The views and opinions expressed in this article are those of the authors and not of the affiliated institutions or funders.

\section{References}

Aaker, D. (1991). Managing brand equity: Capitalizing on the value of a brand name. New York: The Free Press.

Arens, W., Weigold, M., \& Arens, C. (2011). Contemporary advertising and integrated marketing communications (13th edn.). New York: McGraw-Hill.

Bloemer, J.M.M., \& Kasper, J.D.P. (1995). The complex relationship between consumer satisfaction and brand loyalty. Journal of Economic Psychology, 16(2), 311-329. https://doi.org/10.1016/0167-4870(95)00007-B

Bucklin, L. (1963). Retail strategy and the classification of consumer goods. Journal of Marketing, 27(1), 50-55. https://doi.org/10.1177/002224296302700110

Catalyst. (2011). Buying power. Retrieved from http://www.catalyst.org/ publication/256/buying-power

Celen, A., Erdogan, T., \& Taymaz, E. (2005). Fast moving consumer goods competitive conditions and policies. Retrieved from http://www.tepav.org.tr/tur/admin/ dosyabul/upload/EROL_TAYMAZ-Fast_Moving_Consumer_Goodsdosyabul/upload/ER
TEPAVWP0002_0510.pdf

Chaudhuri, A., \& Holbrook, M.B. (2001). The chain of effects from brand trust and brand affect to brand performance. Journal of Marketing, 65(2), 81-93. https:// doi.org/10.1509/jmkg.65.2.81.18255

Cleary, D. (1981). Great American brands. New York: Fairchild.

Cyr, D., Hassanein, K., Head, M., \& Ivanov, A. (2007). The role of social presence in establishing loyalty in e-service environments. Interacting with Computers, 19(1) 43-56. https://doi.org/10.1016/j.intcom.2006.07.010

Delgado-Ballester, E., \& Munuera-Aleman, J.L. (2001). Brand trust in the context of consumer loyalty. European Journal of Marketing, 35(12), 1238-1258. https://doi. org/10.1108/EUM0000000006475

Delgado-Ballester, E., \& Munuera-Aleman, J.L. (2005). Does brand trust matter to brand equity? Journal of Product and Brand Management, 14(3), 187-196. https://doi.org/10.1108/10610420510601058

Ford, J., Ibrahim, E., \& West, D. (2010). Strategic marketing: Creating competitive advantage (2nd edn.). New York: Oxford University Press Inc.

Garbarino, E., \& Johnson, M. (1999). The different roles of satisfaction, trust and commitment in customer relationships. Journal of Marketing, 63(1), 70-87. https://doi.org/10.1177/002224299906300205

Gonzalez, V. (2009). Fast Moving Consumer Goods (FMCG) industry. Retrieved from http://www.articlesbase.com/international-business-articles/fast-movingconsumer-goods-fmcg-industry-855921.html

Graham, P., Harker, D., Harker, M., \& Tuck, M. (1994). Branding food endorsement programmes: The National Heart Foundation of Australia. Journal of Product and Brand Management, 3(4), 31-43. https://doi.org/10.1108/10610429410073110

Heart Mark. (2012). Choose the Heart Mark. Be smart. Retrieved from http://www. heartmark.co.za/

Holton, R. (1958). The distinction between convenience goods, shopping goods, and specialty goods. The Journal of Marketing, 23(1), 53-56. https://doi. org/10.1177/002224295802300108

Jacoby, J. (1971). A model of multi-brand loyalty. Journal of Advertising Research, $11(3), 25-31$.
Keller, K. (1993). Conceptualizing, measuring, and managing customer-based brand equity. Journal of Marketing, 57(1), 1-22. https://doi.org/10.1177/002224299 305700101

Kozup, J., Creyer, E., \& Burton, S. (2003). Making healthful food choices: The influence of health claims and nutrition information on consumers' evaluations of packaged food products and restaurant menu items. Journal of Marketing, 67(2), 19-34. food products and restaurant menu items. Jour
$\mathrm{https}: / /$ doi.org/10.1509/jmkg.67.2.19.18608

Lassar, W., Mittal, B., \& Sharma, A. (1995). Measuring customer-based brand equity. Journal of Consumer Marketing, 12(4), 11-19. https://doi.org/10.1108/ 07363769510095270

Lau, G., \& Lee, S. (1999). Consumers' trust in a brand and the link to brand loyalty Journal of Market Focused Management, 4(1), 341-370. https://doi.org/ 10.1023/A:1009886520142

Levin, A.M., \& Levin, I.P. (2010). Packaging of healthy and unhealthy food products for children and parents: the relative influence of licensed characters and brand names. Journal of Consumer Behaviour, 9(5), 393-402.

Malik, G., \& Guptha, A. (2014). Impact of celebrity endorsements and brand mascots on consumer buying behavior. Journal of Global Marketing, 27(2), 128-143.

Mazis, M., \& Raymond, M. (1997). Consumer perceptions of health claims in advertisements and on food labels. Journal of Consumer Affairs, 31(1), 10-26. https://doi.org/10.1111/j.1745-6606.1997.tb00824.x

Mhurchu, C, \& Gorton, D. (2007). Nutrition labels and claims in New Zealand and Australia: A review of use and understanding. Australian and New Zealand Journal of Public Health, 31(2), 105-112. https://doi.org/10.1111/j.1753-6405.2007.00026.x

Montandon, A.C., Ogonowski, A., \& Botha, E. (2017). Product involvement and the relative importance of health endorsements. Journal of Food Products Marketing, 23(6), 649-667.

Nestle, M., \& Ludwig, D. (2010). Front-of-package food labels public health or propaganda? Journal of the American Medical Association, 303(8), 771-772. https://doi.org/10.1001/jama.2010.179

Nijssen, E. (1999). Success factors of line extensions of fast-moving consumer goods. JournalofMarketing, 33(5),450-474.https://doi.org/10.1108/03090569910262044

Odin, Y., Odin, N., \& Valette-Florence, P. (2001). Conceptual and operational aspects of brand loyalty: an empirical investigation. Journal of Business Research, 53(2), 75-84. https://doi.org/10.1016/S0148-2963(99)00076-4

Rayner, M., Boaz, A., \& Higginson, C. (2001). Consumer use of health related endorsements on food labels in the United Kingdom and Australia. Journal of Nutritional Education, 33(1), 24-30. https://doi.org/10.1016/S1499-4046 (06)60006-7

Rooney, J. (1995). Branding: A trend for today and tomorrow. Journal of Product \& Brand Management, 4(4), 48-55. https://doi.org/10.1108/10610429510097690

Schwartz, B. (2016). The paradox of choice: Why more is less. New york: Ecco Press.

Steenhuis, I., Kroeze, W., Vyth, E., Valk, S., Verbauwen, R., \& Seidell, J. (2010). The effects of using a nutrition logo on consumption and product evaluation of a sweet pastry. Appetite, 55(1), 707-709. https://doi.org/10.1016/j.appet.2010.07.013

Vyth, E., Steenhuis, I., Mallant, S., Mol, Z., Brug, J., Temminghoff, M., ... Seidell, J. (2009). A front-of-pack nutrition logo: A quantitative and qualitative process evaluation in the Netherlands. Journal of Health Communication: International Perspectives, 14(7), 631-645. https://doi.org/10.1080/10810730903204247

Williams, P. (2005). Consumer understanding and use of health claims for foods. Nutrition reviews, 63(7), 256-264.

World Health Organization. (2000). Obesity: Preventing and managing the global epidemic. WHO Technical Support Series 894. Geneva: The World Health Organization.

Yoo, B., \& Donthu, N. (2001). Developing and validating a multidimensional consumerbased brand equity scale. Journal of Business Research, 52(1), 1-14. https://doi. org/10.1016/S0148-2963(99)00098-3

Yoo, B., Donthu, N., \& Lee, S. (2000). An examination of marketing mix elements and brand equity. Journal of the Academy of Marketing Science, 28(2), 195-208. https://doi.org/10.1177/0092070300282002

Young, L., \& Swinburn, B. (2002). Impact of the pick the tick food information programme on the salt content of food in New Zealand. Health Promotion International, 17(1), 13-19. https://doi.org/10.1093/heapro/17.1.13 